\title{
MODIFICATION OF PATHOLOGIC CHANGES IN TOXICOLOGICAL STUDIES DUE TO ENDOTOXIN DERIVED FROM INTESTINAL FLORA \\ II. Effects on Galactosamine-induced Liver Injury with Lactulose, Cyclophosphamide, or Ricinoleic Acid in Rats
}

\author{
Hidetoshi Takagi, Osamu Noguchi, Kaoru Daimaru, Naoshi Shimoji, \\ Hiroyuki Ogasawara, Hisako Fujii-Murakami, Akiko Murata, Yasushi \\ Harada, and Norikazu Inomata \\ Biological Research Laboratories, Lederle (Japan), Ltd.
}

\begin{abstract}
In order to examine the variation of pathologic modifications with endogenous endotoxin, galactosamine $(\mathrm{Ga} 1 \mathrm{~N}) 400 \mathrm{mg} / \mathrm{kg}$ was administered intraperitoneally to male rats combined with lactulose (LTS) $6,000 \mathrm{mg} / \mathrm{kg} /$ day $\times 7$ days, po, cyclophosphamide (CPM) $100 \mathrm{mg} / \mathrm{kg}$, ip, or ricinoleic acid (RA) $2,000 \mathrm{mg} /$ body, po. LTS was used for alteration of intestinal flora, CPM for depression of local intestinal immune system, and RA for disruption of intestinal epithelial barrier. In the GaIN alone group, hepatic changes such as morphologic activation of Kupffer cells, and degeneration and necrosis of hepatocytes in the liver were observed microscopically. However, there were no remarkable changes in the liver in the GalN/LTS group. In the GalN/CPM and GalN/RA groups, although damage of the liver parenchymal cells was milder than those of the GalN alone group, activation of Kupffer cells and mononuclear cell aggregation in the Ga1N/RA gorup were more prominent than the GalN alone group. From the results, as to occurrence of pathologic changes due to endogenous endotoxin, we suggest that the situation of the intestinal flora and the intestinal epithelial barrier, and the balance between quantity of endotoxin and the RES function are important. We concluded that, according to toxicity of a test compound, it is necessary to consider the influence of endogenous endotoxin for assessment and judgement of the toxicity study's results. (J Toxicol Pathol 6 Suppl : 77 88, 1993)

Key words: Galactosamine, Lactulose, Cyclophosphamide, Ricinoleic acid, Endotoxin, Rat, Liver injury
\end{abstract}

\section{Introduction}

We have suggested previously the possibilities of modification of the results in toxicity studies especially of pathologic changes due to endogenous endotoxin ${ }^{1}$. In the present study, in order to clarify whether or not modification against toxicity of a test compound occurs due to

高木英利 野口 修大丸 香下地尚史 小笠原裕之 藤井（村上）久子 村田晃子 原田 寧 猪俣訓一

Accepted for publication: August 13, 1993

Mailing address : Hidetoshi Takagi, Department of Pathology, Biological Research Laboratories, Lederle (Japan), Ltd.

6-34, Kashiwa-cho, 1-chome, Shiki-shi, Saitama 353, Japan. endogenous endotoxin in toxicity studies, a single dose of galactosamine, that is presumed to be in relation to endogenous endotoxin at it's liver injury mechanism, was administered to rats in combination with lactulose, cyclophosphamide, or ricinoleic acid. Treatment with lactulose is used to assume alteration of the intestinal flora, a combination dosing of cyclophosphamide is in case of depression of the systemic immune function including its local intestinal system, and ricinoleic acid is in case of disruption of the intestinal epithelial barrier. 


\section{Materials and Methods}

\section{Compounds}

Galactosamine (GAlN) (D-galactosamine hydrochloride, Wako Pure Chemical Industries, Ltd.) was used as the standard compound that has the toxicity as liver injury. As the combination compound with GalN, lactulose (LTS) (LACTULOSE Syrup "nikken”, Nikken Chemical Co., Ltd.), cyclophosphamide (CPM) (Endoxan Injection, Shionogi and Co., Ltd.), and ricinoleic acid (RA) (Wako Pure Chemical Industries, Co., Ltd.) were used. Physiological saline (ISOTONIC SODIUM CHLORIDE SOLUTION, Otsuka Pharmaceutical Factory, Co., Ltd.) was used as the vehicle for GalN.

\section{Animals and Maintenance}

Mature $\mathrm{Crj}$ : CD (SD) male rats (Charles River Japan, Inc.) were used in this study. The animals were housed individually in stainless steel cages in an air-conditioned room which was kept at a temperature of $20-24^{\circ} \mathrm{C}$ with a relative humidity of $45-55 \%$, with ventilation of about 10 cycles/ hour, and a 12 hours light and dark cycle. The animals were allowed to commercial pellets ( $\mathrm{CE}$ 2, CLEA Japan Inc.) and tap water ad libitum.

\section{Experimental Design}

In order to clarify the endogenous endotoxin in relation to the toxic effects of GalN, after the intestinal flora was changed to inferior occupation of gram negative organisms with repeated oral treatment of LTS $6,000 \mathrm{mg} / \mathrm{kg} /$ day, b.i.d. to rats, a single dose of GalN $400 \mathrm{mg} / \mathrm{kg}$ was administered intraperitoneally to rats at 7 days of LTS dosing, and the animals were euthanized about 6 hours after the first dosing of LTS on the next day of GalN dosing. In addition, the group of LTS $6,000 \mathrm{mg} / \mathrm{kg}$ alone was set up.

In order to clarify the modification of toxicity due to endogenous endotoxin in case of depression of systemic immune function including local intestinal system with a test compound, a single intraperitoneal dose of GalN $400 \mathrm{mg} / \mathrm{kg}$ was administered simultaneously to rats with a single intraperitoneal dosing of CPM $100 \mathrm{mg} / \mathrm{kg}$, and the animals were euthanized about 24 hours after dosing. In addition, the group of CPM $100 \mathrm{mg}$ / $\mathrm{kg}$ alone was set up.

In order to clarify the modification of toxicity due to endogeous endotoxin in case of the disruption of the intestinal mucosal epithelium, namely intestinal epithelial barrier, with a test compound, a single intraperitoneal dose of GalN $400 \mathrm{mg} / \mathrm{kg}$ was administered simultaneously to rats with a single oral dosing of RA $2,000 \mathrm{mg} /$ body, and the animals were euthanized about 24 hours after dosing. In addition, the group of RA $2,000 \mathrm{mg} /$ body alone was set up.

Besides the groups described above, the GalN $400 \mathrm{mg} / \mathrm{kg}$ alone and the vehicle control groups were also set up. Five to six rats belonged in each group. First dosing day to LTS was designated as day 0 of study.

\section{Determination of Fecal pH and Gram Negative Organism Percentage}

In order to clarify the inferior occupation of the gram negative organisms in the intestinal flora with LTS treatment, fecal $\mathrm{pH}$ and a relative percentage of the gram negative and positive organisms in feces were determined for the vehicle control, GalN alone, LTS alone, and GalN/LTS groups. Fecal samples were collected on days 0 , $2,4,6$, and 8 of the study, and after $0.5 \mathrm{~g}$ of each sample were suspended in $5 \mathrm{ml}$ of water for injection, $\mathrm{pH}$ values were measured using $\mathrm{pH}$ indicator paper (Whatman, Ltd.). As to the ratio of the fecal organisms, fecal samples collected in same manner on days 0,4 , and 8 were imprinted on glass slides and Gram's stain was perfromed. The percentage of gram negative organisms in the fecal bacteria was calculated by counting the number of gram negative and positive organisms in 10 fields of each sample under microscope.

\section{Hematology and Clinical Chemistry}

Blood samples were taken from the inferior vena cava of the animals under ether anesthesia for hematology and clinical chemistry. Red blood cell counts (RBC), white blood cell counts (WBC), hemoglobin concentration $(\mathrm{Hb})$, packed cell volume (Ht), and platelet counts (PLT) were determined using Coulter Counter S8/80 (Coulter 
Electronics, Inc.). Serum glucose (Glc), GOT, GPT, alkaline phosphatase (Alp), cholesterol (Chol.), triglycerides (TG), and total bilirubin ( $\mathrm{T}$. Bil.) were determined using Centrifichem Encore ${ }^{\mathrm{TM}}$ (Baker Instrument, Co).

\section{Organ Weight and Microscopic Examination}

The animals were euthanized by exsanguination under ether anesthesia and examined grossly. Samples of the liver, small and large intestines, thymus, spleen, and mesenteric lymph nodes were prepared routinely to paraffin sections and stained with hematoxylin and eosin, and PAS reaction for microscopic examination. Organ weights of the liver, thymus, and spleen were measured.

\section{Statistical Methods}

For hematology, clinical chemistry, and organ weight data, the Student's $t$-test was used to compare each treatment group mean to the vehicle control mean, and to compare each the GalN/ LTS, GalN/CPM, or GalN/RA group mean to the GalN alone group mean. In the case of unequal variances, the Welch approximate $t$-test was used. The use of significant carries the meaning statistically significant.

\section{Results}

Changes of Fecal $p H$ and Gram Negative Organism Percentage

Changes of fecal mean $\mathrm{pH}$ values and the relative percentage of the gram negative organisms in fecal bacteria are shown in Fig. 1.

Fecal mean $\mathrm{pH}$ values of the vehicle control and GalN alone groups transited between 6.4 and 6.8 through the study period. On the other hand, mean $\mathrm{pH} 6.5$ in the LTS alone and GalN/LTS groups on day 0 were changed to $6.0-6.1$ on day 2 , and to 5.9 on days 4 and 6 . Mean $\mathrm{pH}$ values of these LTS groups at necropsy on day 8 were 6.2 and 6.0 , respectively.

The relative percentage of gram negative organisms in fecal bacteria of the vehicle control and GalN alone groups was $85-92 \%$ through the study period. As to the LTS alone and GalN/ LTS groups, the relative percentage was changed to about $50 \%$ on day 4 , and to $35-40 \%$ on day 8 .

\section{Hematology}

Summarized hematological data are shown in

\section{Table 1.}

In comparison with the vehicle control group, significant increases in RBC parameters such as $\mathrm{RBC}, \mathrm{Hb}$, and $\mathrm{Ht}$ was seen in the GalN alone group. A similar change of RBC parameters were also seen in the GalN/CPM and GalN/RA groups. Significant decreases in the RBC parameter, WBC, and PLT were seen in the CPM alone group. The changes in WBC and PLT were also seen in the GalN/CPM group, and the WBC changes in the GalN/RA group, but it was only slight.

In comparison with the GalN alone group between the GalN/LTS, GalN/CPM, or GalN/
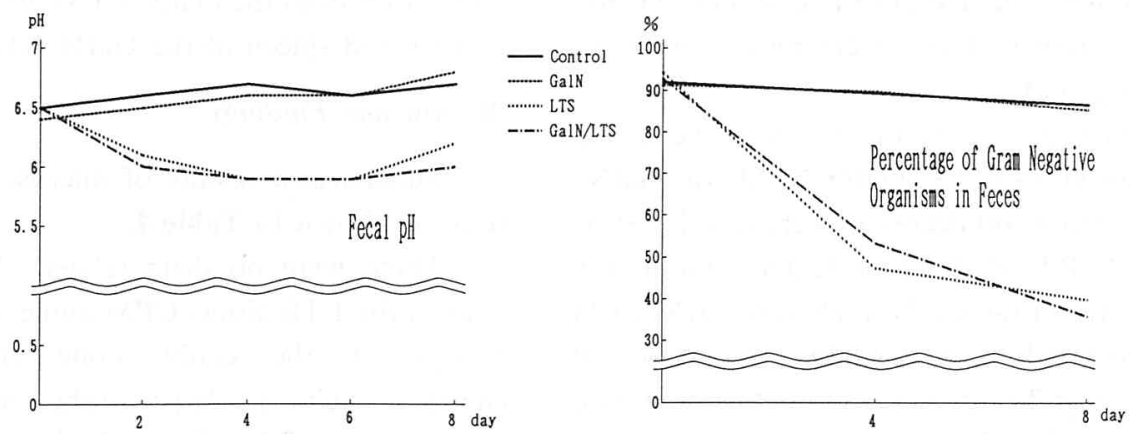

Fig. 1. Fecal pH and relative percentage of gram negative organisms in male rats receiving a single dose of galactosamine, GalN $(400 \mathrm{mg} / \mathrm{kg})$ combined with lactulose, LTS $(6,000 \mathrm{mg} / \mathrm{kg})$

First dosing day of LTS is designated as day 0. GalN was administered at day 7 of the 8-day LTS treatment period. 
Table 1. Hematology of Male Rats Receiving a Single Dose of Galactosamine (Ga1N) Combined with Lactulose (LTS), Cyclophosphamide (CPM), or Ricinoleic Acid (RA)

\begin{tabular}{|c|c|c|c|c|c|c|c|c|c|}
\hline \multicolumn{4}{|c|}{ Dose $(\mathrm{mg} / \mathrm{kg})$} & \multirow{2}{*}{$\begin{array}{l}\text { No. } \\
\text { of } \\
\text { Rats }\end{array}$} & \multirow{2}{*}{$\begin{array}{c}\text { WBC } \\
\times 10^{2} \\
\left(\mathrm{~mm}^{3}\right)\end{array}$} & \multirow{2}{*}{$\begin{array}{c}\mathrm{RBC} \\
\times 10^{4} \\
\left(\mathrm{~mm}^{3}\right)\end{array}$} & \multirow{2}{*}{$\underset{(\mathrm{g} / \mathrm{dl})}{\mathrm{Hb}}$} & \multirow{2}{*}{$\begin{array}{l}\mathrm{Ht} \\
(\%)\end{array}$} & \multirow{2}{*}{$\begin{array}{c}\text { PLT } \\
\times 10^{3} \\
\left(\mathrm{~mm}^{3}\right)\end{array}$} \\
\hline $\begin{array}{l}\text { GalNa } \\
\text { (ip) }\end{array}$ & $\begin{array}{l}\text { LTS } \\
\text { (po) }\end{array}$ & $\begin{array}{l}\text { CPM } \\
\text { (ip) }\end{array}$ & $\begin{array}{l}\mathrm{RA}^{\mathrm{b}} \\
\text { (po) }\end{array}$ & & & & & & \\
\hline 0 & - & - & - & 5 & $164 \pm 22$ & $729 \pm 11$ & $15.0 \pm 0.2$ & $44.4 \pm 1.0$ & $1062 \pm 38$ \\
\hline 0 & 6000 & - & - & 4 & $182 \pm 59$ & $758 \pm 26$ & $15.8 \pm 0.6^{*}$ & $46.3 \pm 1.9$ & $1079 \pm 59$ \\
\hline 0 & - & 100 & - & 3 & $7 \pm 2^{* *}$ & $682 \pm 18^{* *}$ & $14.0 \pm 0.7^{*}$ & $40.6 \pm 2.3^{*}$ & $636 \pm 88^{* *}$ \\
\hline 0 & - & - & 2000 & 4 & $148 \pm 39$ & $739 \pm 29$ & $15.6 \pm 0.6$ & $45.9 \pm 1.8$ & $1071 \pm 55$ \\
\hline 400 & - & - & - & 5 & $144 \pm 45$ & $827 \pm 50^{* *}$ & $17.4 \pm 1.0^{* *}$ & $50.4 \pm 3.3^{*}$ & $1063 \pm 118$ \\
\hline 400 & 6000 & - & - & 6 & $135 \pm 34$ & $744 \pm 36^{+}$ & $15.6 \pm 0.9^{+}$ & $46.2 \pm 2.6^{+}$ & $1071 \pm 80$ \\
\hline 400 & - & 100 & - & 5 & $9 \pm 1^{* *++}$ & $795 \pm 37^{*}$ & $16.8 \pm 1.0^{*}$ & $49.0 \pm 3.6^{*}$ & $551 \pm 44^{* *++}$ \\
\hline 400 & - & - & 2000 & 5 & $121 \pm 27^{*}$ & $824 \pm 32 * *$ & $17.4 \pm 0.7^{* *}$ & $51.8 \pm 2.1 * *$ & $1088 \pm 80$ \\
\hline
\end{tabular}

a) GalN was administered simultaneously with CPM or RA, or administered on day 7 of LTS treatment. b) $\mathrm{mg} /$ body

Each value represents the mean \pm standard deviation of each group.

The statistical comparison in each case is with the vehicle control group $\left({ }^{*} \mathrm{p} \leqq 0.05,{ }^{* *} \mathrm{p} \leqq 0.01\right)$, and the comparison in each Ga1N dosing group is with the Ga1N alone group $\left({ }^{+} \mathrm{p} \leqq 0.05,{ }^{++} \mathrm{p} \leqq 0.01\right)$.

RA group, a significant decrease was seen in RBC parameter of the GalN/LTS group, and in WBC and PLT of the GalN/CPM group.

\section{Clinical Chemistry}

Summarized clinical chemistrical data are shown in Table 2.

In comparison with the vehicle control group, significant decreases in Glc and Chol., and significant increases in GOT, GPT, Alp, and T. Bil. were seen in the GalN alone group. Although similar changes, except the T. Bil. were also seen in the GalN/CPM and GalN/RA groups, the changes in GOT, GPT, and Alp were slight as compared to those of the GalN alone group. In addition, a slight increase in GPT and a slight decrease in Chol. were also seen in the GalN/LTS group.

In comparison with the GalN alone group between the GalN/LTS, GalN/CPM, or GalN/ RA group, significant decreases were seen in GOT, GPT, and T. Bil. of all of the GalN combination groups, in Alp of the GalN/LTS and GalN/CPM groups, and in Chol. of the GalN/RA group. In addition, a significant increases in Glc was also seen in the GalN/LTS group.

\section{Organ Weight}

Organ Weight data are summarized in Table
3.

In comparison with the vehicle control group, significant decreases in both absolute and relative weights of the liver were seen in the GalN alone group, and the GalN/LTS, GalN/CPM, and GalN/RA groups. Significant decreases in both absolute and relative weights of the thymus and spleen were seen in the CPM alone and GalN/ CPM groups, and these changes in the thymus were also seen in the RA alone, and the LTS alone and GalN/LTS groups.

In comparison with the GalN alone group between the GalN/LTS, GalN/CPM, or GalN/ RA group, significant decreases in both absolute and relative weights were seen in the liver, thymus, and spleen from the GalN/CPM group, and in the thymus and spleen of the GalN/LTS group.

\section{Microscopic Findings}

Summarized results of microscopic examination are shown in Table 4.

There were no drug related changes in the liver in the LTS alone, CPM alone, and RA alone groups. In the GalN alone group, hepatic changes such as hypertrophy and increased phagocytosis of Kupffer cells, hypertrophy, cytoplasmic acidophilic body, and degeneration and necrosis of hepatocytes, and decreased glycogen deposition were observed (Fig. 2). Similar he- 
Table 2. Clinical Chemistry of Male Rats Receiving a Single Dose of Galactosamine (GalN) Combined with Lactulose (LTS), Cyclophosphamide (CPM), or Ricinoleic Acid (RA)

\begin{tabular}{|c|c|c|c|c|c|c|c|c|c|c|c|}
\hline \multicolumn{4}{|c|}{ Dose $(\mathrm{mg} / \mathrm{kg})$} & \multirow{2}{*}{$\begin{array}{c}\text { No. } \\
\text { of } \\
\text { Rats }\end{array}$} & \multirow{2}{*}{$\begin{array}{c}\text { Glc } \\
(\mathrm{mg} / \mathrm{dl})\end{array}$} & \multirow{2}{*}{$\begin{array}{c}\text { BUN } \\
(\mathrm{mg} / \mathrm{dl})\end{array}$} & \multirow{2}{*}{$\begin{array}{l}\text { GOT } \\
(\mathrm{U} / 1)\end{array}$} & \multirow{2}{*}{$\begin{array}{l}\text { GPT } \\
(\mathrm{U} / \mathrm{l})\end{array}$} & \multirow{2}{*}{$\begin{array}{c}\text { Alp } \\
(\mathrm{U} / \mathrm{l})\end{array}$} & \multirow{2}{*}{$\begin{array}{l}\text { Chol. } \\
(\mathrm{mg} / \mathrm{dl})\end{array}$} & \multirow{2}{*}{$\begin{array}{c}\text { T. Bil. } \\
(\mathrm{mg} / \mathrm{dl})\end{array}$} \\
\hline $\begin{array}{c}\text { GalN }^{a} \\
\text { (ip) }\end{array}$ & $\begin{array}{l}\text { LTS } \\
\text { (po) }\end{array}$ & $\begin{array}{l}\text { CPM } \\
\text { (ip) }\end{array}$ & $\begin{array}{l}\mathrm{RA}^{\mathrm{b}} \\
\text { (po) }\end{array}$ & & & & & & & & \\
\hline 0 & - & - & - & 5 & $208 \pm 39$ & $23 \pm 2$ & $62 \pm 16$ & $28 \pm 3$ & $167 \pm 26$ & $76 \pm 14$ & $0.27 \pm 0.03$ \\
\hline 0 & 6000 & - & - & 6 & $225 \pm 62$ & $20 \pm 3^{*}$ & $55 \pm 18$ & $30 \pm 5$ & $145 \pm 21$ & $68 \pm 8$ & $0.24 \pm 0.07$ \\
\hline 0 & - & 100 & - & 5 & $220 \pm 46$ & $22 \pm 3$ & $57 \pm 9$ & $25 \pm 7$ & $128 \pm 37$ & $71 \pm 9$ & $0.21 \pm 0.08$ \\
\hline 0 & - & - & 2000 & 5 & $265 \pm 51$ & $18 \pm 2^{* *}$ & $54 \pm 9$ & $31 \pm 9$ & $162 \pm 49$ & $58 \pm 10^{*}$ & $0.17 \pm 0.06^{*}$ \\
\hline 400 & - & - & - & 5 & $124 \pm 19^{* *}$ & $22 \pm 2$ & $3220 \pm 1502 * *$ & $2288 \pm 667^{* *}$ & $318 \pm 43^{* *}$ & $45 \pm 12 * *$ & $0.82 \pm 0.33^{*}$ \\
\hline 400 & 6000 & - & - & 6 & $201 \pm 19^{++}$ & $17 \pm 1^{* *++}$ & $77 \pm 23^{++}$ & $55 \pm 21^{*++}$ & $170 \pm 61^{++}$ & $56 \pm 15^{*}$ & $0.27 \pm 0.10^{+}$ \\
\hline 400 & - & 100 & - & 5 & $114 \pm 11^{* *}$ & $21 \pm 3$ & $800 \pm 417^{*+}$ & $636 \pm 320^{*+}$ & $159 \pm 37^{++}$ & $39 \pm 17^{* *}$ & $0.38 \pm 0.21^{+}$ \\
\hline 400 & - & - & 2000 & 5 & $145 \pm 18^{*}$ & $21 \pm 3$ & $540 \pm 281^{*+}$ & $437 \pm 218^{*+}$ & $302 \pm 97^{*}$ & $16 \pm 6^{* *++}$ & $0.23 \pm 0.07^{+}$ \\
\hline
\end{tabular}

a) GalN was administered simultaneously with CPM or RA, or administered on day 7 of LTS treatment.

b) $\mathrm{mg} /$ body

Each value represents the mean \pm standard deviation of each group.

The statistical comparison in each case is with the vehicle control group $\left({ }^{*} \mathrm{p} \leqq 0.05,{ }^{* *} \mathrm{p} \leqq 0.01\right)$, and the comparison in each GalN dosing group is with the GalN alone group $\left({ }^{+} \mathrm{p} \leqq 0.05,{ }^{++} \mathrm{p} \leqq 0.01\right)$. 
Table 3. Organ Weight of Male Rats Receiving a Single Dose of Galactosamine (GalN) Combined with Lactulese (LTS), Cyclophosphamide (CPM), or Ricinoleic Acid (RA)

\begin{tabular}{|c|c|c|c|c|c|c|c|c|c|c|c|}
\hline \multicolumn{4}{|c|}{ Dose $(\mathrm{mg} / \mathrm{kg})$} & \multirow{2}{*}{$\begin{array}{l}\text { No. } \\
\text { of } \\
\text { Rats }\end{array}$} & \multirow{2}{*}{$\begin{array}{l}\text { Body } \\
\text { Weight } \\
\text { (g) }\end{array}$} & \multicolumn{3}{|c|}{ Absolute } & \multicolumn{3}{|c|}{ Relative } \\
\hline $\begin{array}{l}\text { GalN }^{\mathrm{a}} \\
\text { (ip) }\end{array}$ & $\begin{array}{l}\text { LTS } \\
\text { (po) }\end{array}$ & $\begin{array}{l}\text { CPM } \\
\text { (ip) }\end{array}$ & $\begin{array}{l}\mathrm{RA}^{\mathrm{b}} \\
\text { (po) }\end{array}$ & & & $\begin{array}{l}\text { Liver } \\
(\mathrm{g})\end{array}$ & $\begin{array}{l}\text { Thymus } \\
\text { (mg) }\end{array}$ & $\begin{array}{l}\text { Spleen } \\
\text { (mg) }\end{array}$ & $\begin{array}{c}\text { Liver } \\
\text { (g/100 g } \\
\text { body wt.) }\end{array}$ & $\begin{array}{l}\text { Thymus } \\
\text { (mg/100 g } \\
\text { body wt.) }\end{array}$ & $\begin{array}{c}\text { Spleen } \\
\text { (mg/100 g } \\
\text { body wt.) }\end{array}$ \\
\hline 0 & - & - & - & 5 & $\begin{array}{r}444 \\
\pm 15\end{array}$ & $\begin{array}{r}18.3 \\
\pm 1.5\end{array}$ & $\begin{array}{r}632 \\
\pm 107\end{array}$ & $\begin{array}{r}786 \\
\pm \quad 50\end{array}$ & $\begin{array}{r}4.12 \\
\pm 0.29\end{array}$ & $\begin{array}{r}142 \\
\pm 23\end{array}$ & $\begin{array}{r}177 \\
\pm 10\end{array}$ \\
\hline 0 & 6000 & - & - & 6 & $\begin{array}{r}442 \\
\pm 35\end{array}$ & $\begin{array}{r}15.9 \\
+2.4\end{array}$ & $\begin{array}{r}468^{*} \\
\pm \quad 70\end{array}$ & $\begin{array}{r}752 \\
+133\end{array}$ & $\begin{array}{r}3.76 \\
\pm 0.32\end{array}$ & $\begin{array}{l}112^{*} \\
\pm 17\end{array}$ & $\begin{array}{r}178 \\
\pm 27\end{array}$ \\
\hline 0 & - & 100 & - & 5 & $\begin{array}{l}404^{* *} \\
\pm 17\end{array}$ & $\begin{array}{r}16.6 \\
\pm 0.7\end{array}$ & $\begin{aligned} & 123^{* *} \\
\pm & 16\end{aligned}$ & $\begin{array}{l}385^{* *} \\
\pm \quad 34\end{array}$ & $\begin{array}{r}4.11 \\
\pm 0.10\end{array}$ & $\begin{array}{l}31^{* *} \\
\pm \quad 5\end{array}$ & $\begin{aligned} & 96^{* *} \\
\pm & 10\end{aligned}$ \\
\hline 0 & - & - & 2000 & 5 & $\begin{array}{r}420 \\
+29\end{array}$ & $\begin{array}{r}16.8 \\
\pm 2.8\end{array}$ & $\begin{array}{r}448^{*} \\
\pm \quad 66\end{array}$ & $\begin{array}{r}659^{*} \\
\pm \quad 88\end{array}$ & $\begin{array}{r}4.09 \\
\pm 0.40\end{array}$ & $\begin{array}{l}107^{*} \\
\pm 13\end{array}$ & $\begin{array}{r}157 \\
\pm 19\end{array}$ \\
\hline 400 & - & - & - & 5 & $\begin{array}{l}404^{* *} \\
\pm 21\end{array}$ & $\begin{array}{l}14.5^{* *} \\
\pm 1.1\end{array}$ & $\begin{array}{r}496^{*} \\
\pm \quad 64\end{array}$ & $\begin{array}{r}800 \\
\pm \quad 31\end{array}$ & $\begin{aligned} & 3.59 * \\
\pm & 0.22\end{aligned}$ & $\begin{array}{r}123 \\
\pm 14\end{array}$ & $\begin{array}{l}199^{*} \\
\pm 16\end{array}$ \\
\hline 400 & 6000 & - & - & 6 & $\begin{array}{r}427 \\
\pm 14\end{array}$ & $\begin{array}{l}15.4^{* *} \\
\pm 1.2\end{array}$ & $\begin{array}{l}425^{*+} \\
\pm \quad 30\end{array}$ & $\begin{array}{l}691^{*+} \\
\pm \quad 77^{2}\end{array}$ & $\begin{aligned} & 3.60^{* *} \\
\pm & 0.23\end{aligned}$ & $\begin{array}{l}100^{*+} \\
\pm 6\end{array}$ & $\begin{array}{c}162^{++} \\
16\end{array}$ \\
\hline 400 & - & 100 & - & 5 & $\begin{array}{l}374^{* *} \\
\pm 21\end{array}$ & $\begin{array}{l}12.1^{* *+} \\
\pm 1.0\end{array}$ & $\begin{aligned} & 88^{* *++} \\
\pm & 17\end{aligned}$ & $\begin{aligned} & 394^{* *+} \\
\pm & 49\end{aligned}$ & $\begin{aligned} & 3.24^{* *++} \\
\pm & 0.15\end{aligned}$ & 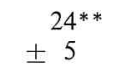 & $\begin{array}{l}105^{* *} \\
\pm \quad 8\end{array}$ \\
\hline 400 & - & - & 2000 & 5 & $\begin{array}{l}398 * * \\
\pm 22\end{array}$ & $\begin{array}{l}13.2^{* *} \\
+1.0\end{array}$ & $\begin{array}{l}452^{*} \\
\pm 103\end{array}$ & $\begin{array}{r}746 \\
+114\end{array}$ & $\begin{aligned} & 3.04^{* *+} \\
\pm & 0.32\end{aligned}$ & $\begin{array}{r}114 \\
\pm 26\end{array}$ & $\begin{array}{r}187 \\
\pm 29\end{array}$ \\
\hline
\end{tabular}

a) GalN was administered simultaneously with CPM or RA, or administered on day 7 of LTS treatment.

b) $\mathrm{mg} /$ body

Each value represents the mean \pm standard deviation of each group.

The statistical comparison in each case is with the vehicle control grozp ( $\left.{ }^{*} 6 \leqq 0.05,{ }^{* *} \mathrm{p} \leqq 0.01\right)$, and the compari-

son in each GalN dosing group is with the GalN alone group $\left({ }^{+} \mathrm{p} \leqq 0.05,{ }^{++} \mathrm{p} \leqq 0.01\right)$.

patic changes were observed in the GalN/CPM and GalN/RA groups, but they were relatively milder than those of the GalN alone group (Fig. 3). In the GalN/RA group, however, morphologic activation of Kupffer cells and aggregation of nomonuclear cells were more prominent than the GalN alone group (Fig. 4). There were no remarkable hepatic changes in the GalN/LTS group except for slight hypertrophy of hepatocytes (Fig. 5).

Besides hepatic changes, cell depletion in the mucosal lamina propria of the small intestine, and severe lymphoid depletion in the thymus, spleen, and mesentric lymph nodes of the CPM alone and GalN/CPM groups (Figs. 6, 7), and vacuolar changes of the mucosal epithelial cells of the small intestine of the RA alone and GalN/RA groups were observed (Fig. 8).

\section{Discussion}

It is known that endogenous endotoxins derived from gram negative organism in the intestinal flora pass from the intestinal mucosa into the circulation, and are then transported to the liver through the portal vein where they are finally treated by Kupffer cells. Furthermore, the intestinal epithelial barrier and local intestinal immune system $^{2}$ are also constructed for protection from excessive endotoxin influx. When modification of the toxicity study's results due to endogenous endotoxin is presumed, the causes are considered to be usually those concerning alteration of the intestinal flora and/or disruption of the intestinal barrier mechanisms. Therefore, we investigated whether or not the modification occurs with these causes in the toxicity study, using GalN liver injury which is presumed to be attributable to endogenous endotoxins.

GalN, a kind of mucopolysaccharide, is accepted and frequently used for making animal models of liver disease, since this compound can cause various types of liver injury depending on dosing methods, and has a low risk in handling ${ }^{3,4}$. It is known that the mechanisms of liver injury with GalN are inhibition of RNA and protein synthesis in hepatocytes in relation to depletion of uridine phosphate during the process of its metabo- 
Table 4. Microscopic Findings in Male Rats Receiving a Single Dose of Galactosamine (GalN) Combined with Lactulose (LTS), Cyclphosphamide (CPM), or Ricinoleic Acid (RA)

\begin{tabular}{|c|c|c|c|c|c|c|c|c|}
\hline $\begin{array}{l}\text { GalN }(\mathrm{mg} / \mathrm{kg}, \text { ip }) \\
\operatorname{LTS}(\mathrm{mg} / \mathrm{kg}, \text { po } \times 8 \text { days }) \\
\text { CPM }(\mathrm{mg} / \mathrm{kg}, \text { ip }) \\
\text { RA }(\mathrm{mg} / \text { body, po })\end{array}$ & $\begin{array}{l}0 \\
- \\
- \\
-\end{array}$ & $\begin{array}{c}0 \\
6000 \\
- \\
-\end{array}$ & $\begin{array}{l}0 \\
- \\
100 \\
-\end{array}$ & $\begin{array}{c}0 \\
- \\
- \\
2000\end{array}$ & $\begin{array}{l}400 \\
- \\
- \\
-\end{array}$ & $\begin{array}{c}400 \\
6000 \\
- \\
-\end{array}$ & $\begin{array}{l}400 \\
- \\
100 \\
-\end{array}$ & $\begin{array}{c}400 \\
- \\
- \\
2000\end{array}$ \\
\hline No. of Animals & 5 & 6 & 5 & 5 & 5 & 6 & 5 & 5 \\
\hline \multicolumn{9}{|l|}{ Liver : } \\
\hline $\begin{array}{l}\text { Hypertrophy of Kupffer cells } \\
\text { with phagocytosis }\end{array}$ & - & - & - & - & \pm & - & \pm & + \\
\hline Hypertrophy of hepatocytes & - & - & - & - & + & \pm & + & \pm \\
\hline Acidophilic body in hepatocytes & - & - & - & - & \# & - & + & \pm \\
\hline $\begin{array}{l}\text { Degenerative necrosis of } \\
\text { hepatocytes }\end{array}$ & - & - & - & - & H & - & \pm & + \\
\hline Focal coagulative necrosis & - & - & - & - & - & - & \pm & - \\
\hline MNC aggregation & - & - & - & - & \pm & - & - & + \\
\hline Glycogen deposition & H & \# & \# & $\#$ & \pm & H & - & \pm \\
\hline \multicolumn{9}{|l|}{ Intestine : } \\
\hline $\begin{array}{l}\text { Degeneration of mucosal epithelial } \\
\text { cells in small intestine }\end{array}$ & - & - & - & + & - & - & - & + \\
\hline $\begin{array}{l}\text { Decreased cellularity } \\
\text { in lamina propria }\end{array}$ & - & - & + & - & - & - & + & - \\
\hline \multicolumn{9}{|l|}{ Thymus : } \\
\hline Cortical lymphoid depletion & - & - & \# & - & - & - & \# & - \\
\hline \multicolumn{9}{|l|}{ Spleen : } \\
\hline Follicular lymphoid depletion & - & - & H & - & - & - & \# & - \\
\hline $\begin{array}{l}\text { M. Lymph Nodes: } \\
\text { Cortical lymphoid depletion }\end{array}$ & - & - & \# & - & - & - & \# & - \\
\hline
\end{tabular}

GalN was administered simultaneously with CPM or RA, or administered on day 7 of LTS treatment. Magnitude of grade: Mean grade in 3 animals above of each group which showed pathological changes. $-=$ Not remarkable $\pm=$ slight $\quad+$ mild $\quad+=$ moderate $\#=$ severe

lism, inhibition of plasma membranous glycoprotein, and glycolipid synthesis, and cytoplasmic changes due to glycogen deficiency ${ }^{3}$. Furthermore, it is said that the changes with GalN are potentiated by the deteriorated function of RES, activation of complement system, and influence to the coagulation system due to simultaneously occurring endotoxemia ${ }^{3-7}$.

LTS as a disaccharide is not digested and absorbed after oral dosing, and produces organic acid and decreases the $\mathrm{pH}$ value with utilization and disintegration by lactic acid bacilli. Concerning this $\mathrm{pH}$ change, LTS dosing results in inhibition of generation of endotoxin from the intestinal flora because of less gram negative bacteria. In addition, dosing of a large amount of LTS showed a depressued RES function ${ }^{8,9}$.
At first, we investigated the magnitude of endogenous endotoxin effects among the liver injury with GalN using rats receiving a single dosing of GalN after pretreatment period with LTS, which were monitered periodically for fecal $\mathrm{pH}$ and relative percentage of gram negative bacteria. GalN was dosed on day 7 , when the fecal parameters were kept at lower values. There were no remarkable changes in hematology, clinical chemistry, and microscopic examination. Therefore, it seemed that almost all the toxicities with GalN occurred in relation to endogenous endotoxin. These results are supported by the demonstrations in the report described above $e^{8,9}$, and indicate that toxicity with a certain compound is modified by the alteration of intestinal flora.

Next to the study using LTS, we examined 


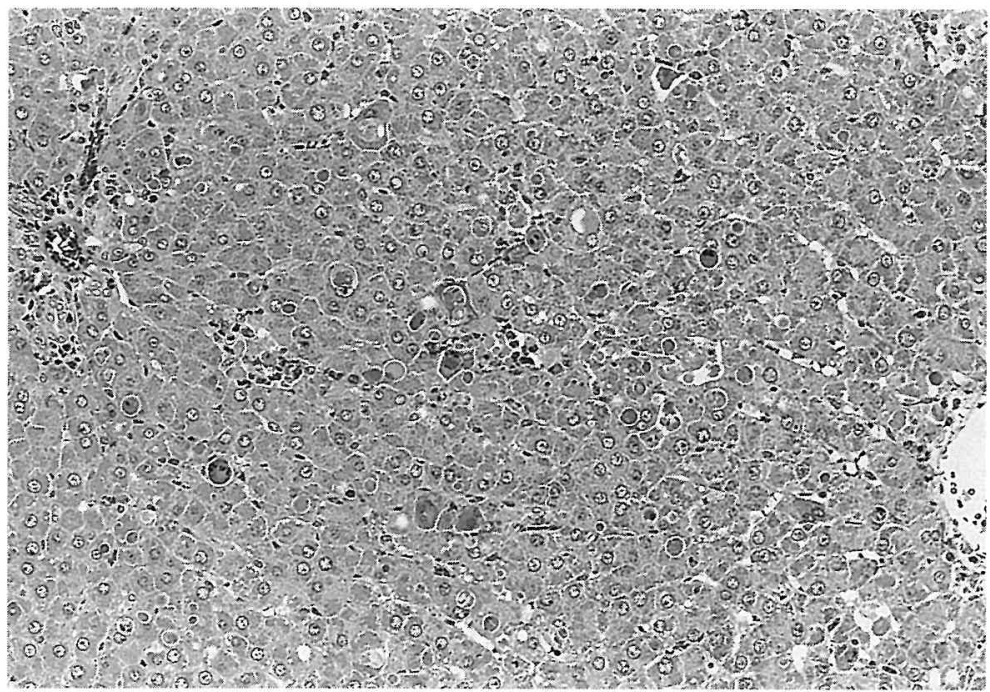

Fig. 2. Liver from rat receiving a single dose of GalN $400 \mathrm{mg} / \mathrm{kg}$.

Note cytoplasmic acidophilic body, hypertrophy, and necrosis of hepatocytes, and hypertrophy of Kupffer cells. HE $\times 200$

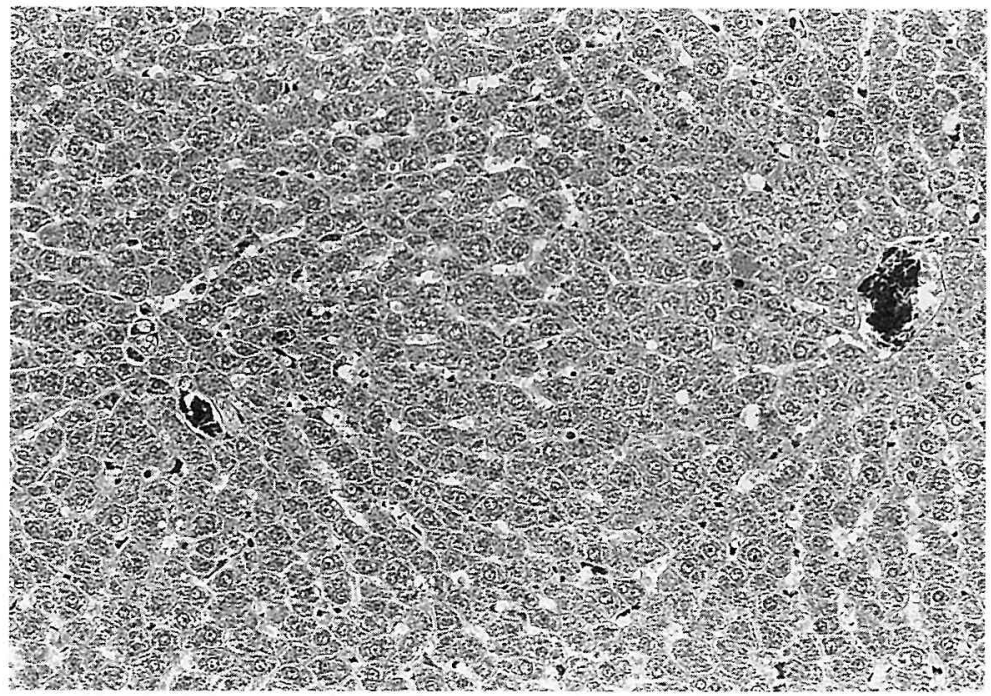

Fig. 3. Liver from rat receiving a single dose of GalN $400 \mathrm{mg} / \mathrm{kg}$ combined with $\mathrm{LTS} 6,000 \mathrm{mg} / \mathrm{kg} / \mathrm{day}$.

There are no remarkable changes in hepatocytes or Kupffer cells. $\mathrm{HE} \times 200$

whether pathologic changes with GalN are modified by endogenous endotoxin, using rats receiving GalN combined with CPM or RA.

Anti-neoplastic agent CPM has a potential function to depress RES activity. A single dose of CPM $100 \mathrm{mg} / \mathrm{kg}$ was used to increase circulating endotoxins from the intestinal flora by disruption of the defense mechanism of the local intestinal immune system. In the GalN alone and GalN/
CPM groups, although cell depletion in the intestinal mucosal lamina propria and lymphoid organs were prominent, degree of liver injury was less than that of the GalN alone group, except for decreased glycogen deposition. Hematology and clinical chemistry revealed the same tendency. These results are considered to be due to depressed non-specific immune mechanisms of RES in the liver with dosing of CPM. It has been reported 


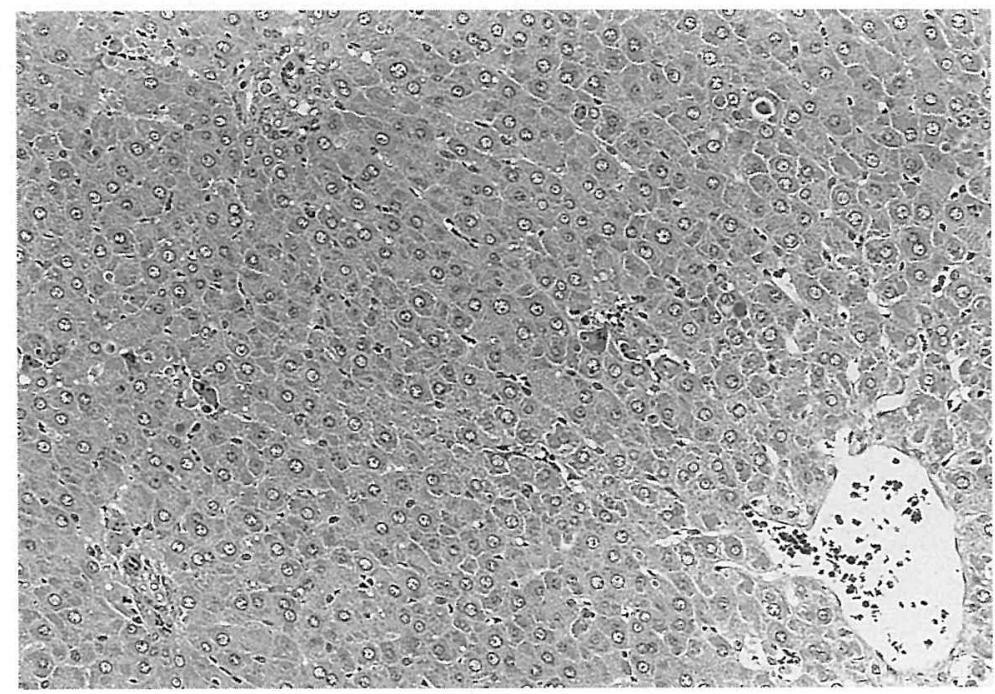

Fig. 4. Liver from rat receiving a single dose of GalN $400 \mathrm{mg} / \mathrm{kg}$ combined with CPM $100 \mathrm{mg} / \mathrm{kg}$. Note hypertrophy of hepatocytes, and necrotic foci. No hypertrophy of Kupffer cells is observed. $\mathrm{HE} \times 200$

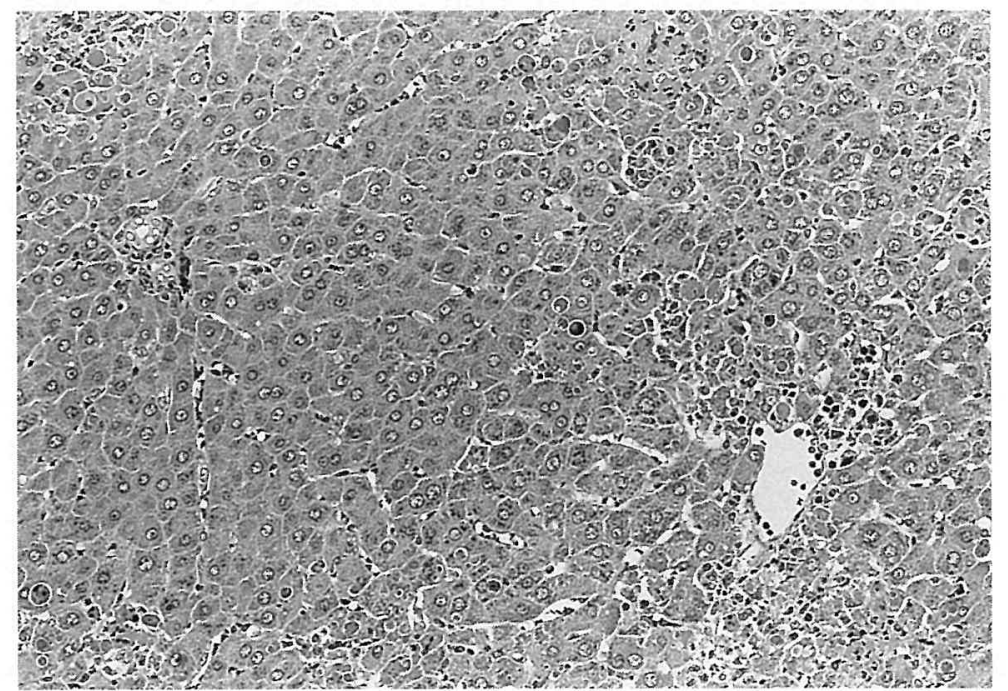

Fig. 5. Liver from rat receiving a single dose of GalN $400 \mathrm{mg} / \mathrm{kg}$ combined with RA 2,000 mg/ $\mathrm{kg}$. Note cytoplasmic acidophilic body, hypertrohy, and necrosis of hepatocytes. Mononuclear cell aggregation and hypertrophy of Kupffer cells are prominent. HE $\times 200$

that it is necessary to activate Kupffer cells by contact with endotoxin in order to cause liver injury with endotoxin ${ }^{6,10}$. The results by this combination use are compatible with the conclusions of the report that there is functional suppression of Kupffer cells beforehand in toxin-resistant mouse ${ }^{6}$. From these facts, it is considered that the modification depends upon circumstances of the
RES function in liver, if endotoxin influx occurs following suppression of local intestinal immune system. Therefore, the balance between the quantity of circulating endotoxins and the degree of RES activation is important in causing pathologic changes with endotoxin.

RA is the active ingredient generated by disintegration of castor oil as laxative in the intestinal 


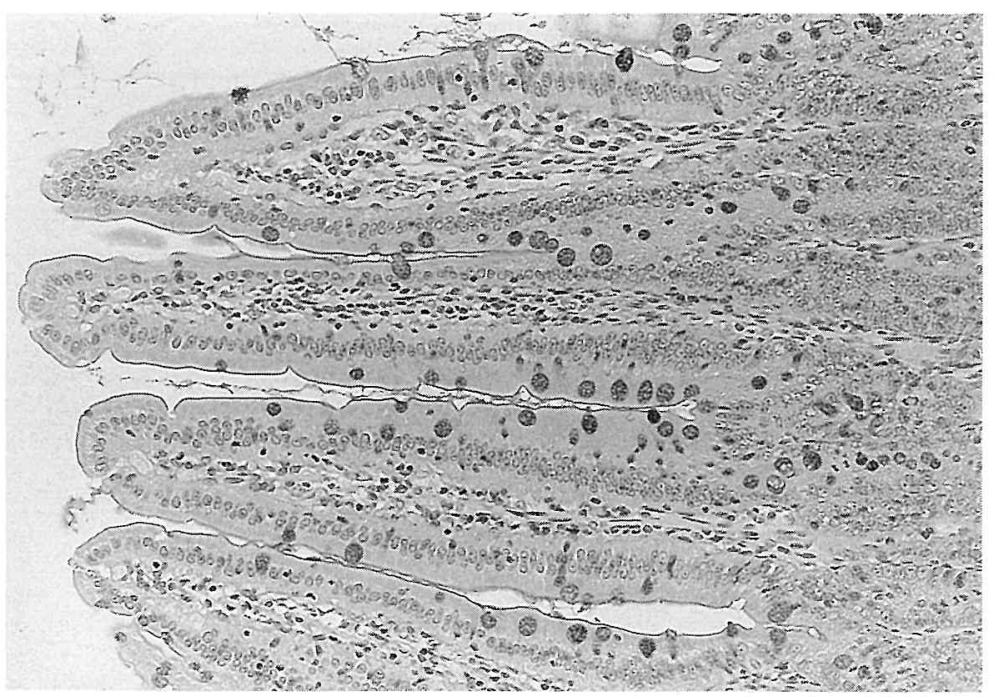

Fig. 6. Small intestine from rat receiving a single dose of GalN $400 \mathrm{mg} / \mathrm{kg}$ combined with CPM $100 \mathrm{mg} / \mathrm{kg}$. Note depletion of cells in mucosal lamina propria. PAS reaction, $\times 200$

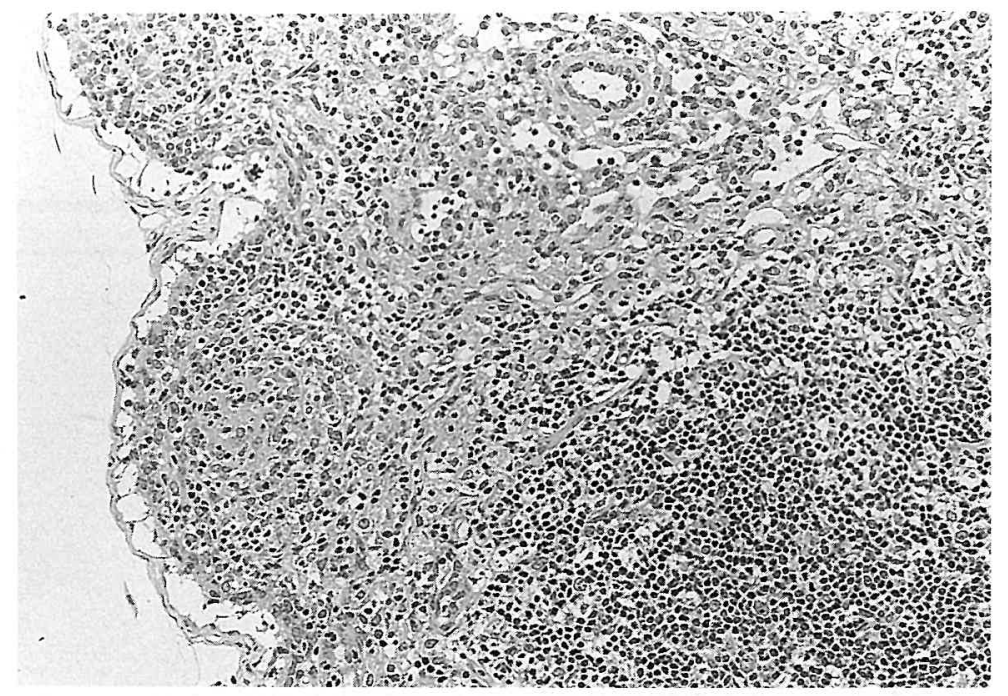

Fig. 7. Mesenteric lymph node from rat receiving a single dose of GalN $400 \mathrm{mg} / \mathrm{kg}$ combined with CPM 100 $\mathrm{mg} / \mathrm{kg}$. Note depletion of cortical lymphoid tissues. HE $\times 200$

lumen, and it has been said that its effecacy was due to inhibition of watery absorption and constriction of circular muscles of the intestine ${ }^{11}$. It is also known that RA stimulates secretion of water and electrolytes, and mucosal injury induced by alteration of mucosal permeability due to its surfactant property as a fatty acid ${ }^{12}$. Berg, RD has certified bacterial translocation from intestinal flora to some organs such as the liver and lymph nodes in mice using this RA surfactant property to the intestinal mucosa, namely disruption of intestinal epithelial barrier ${ }^{2}$. In the present study, we investigated whether endogenous endotoxin derived from the intestinal flora influenced GalN toxicity when intestinal epithelial barrier was disrupted with RA treatment in rats.

In the GalN/RA group compared with the GalN alone group, improvement of liver dysfunction was noted in clinical pathological parameters such as elevated serum GOT and GPT, and micro- 


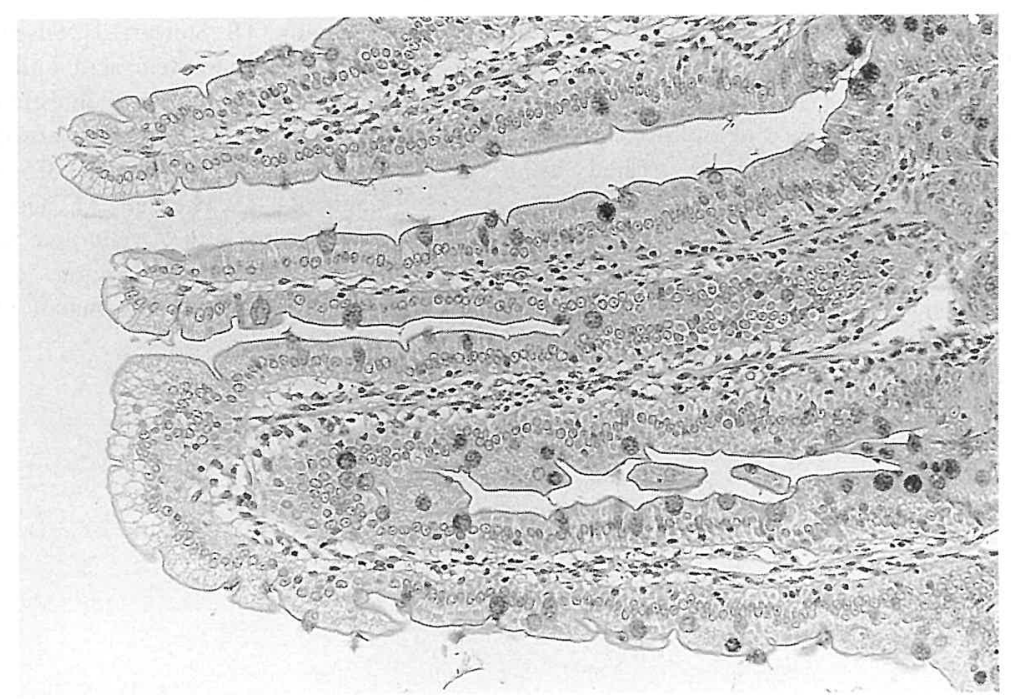

Fig. 8. Small intestine from rat receiving a single dose of GalN $400 \mathrm{mg} / \mathrm{kg}$ combined with RA $2,000 \mathrm{mg} / \mathrm{kg}$. Note vacuolar change of epithelial cells. PAS reaction, $\times 200$

scopic hepatic changes. However, the degree of Kupffer cell activation and mononuclear cell aggregation was greater than those of the GalN alone group. From these results, it is presumed that some materials are transported from the intestine with mucosal alteration to the liver, except endogenous endotoxin due to GalN. Although we could not clarify the reason for this milder hepatic injury, the causes may be due to tentative cleaning effects on the intestinal flora with its laxative property and/or inhibition of the intestinal bacteria with its surfactant property. Therefore, since the changes of Kupffer cells and mononuclear cell aggregaition were noted in this study, it is suggested that the possibilities of modification due to endogenous endotoxin agents which can cause distruption of the intestinal barrier.

In summary, from the results in the rat study of GalN combined with LTS, CPM, or RA, it is suggested that the condition of the intestinal flora and the intestinal epithelial barrier, and the balance of endogenous endotoxin quantity and RES function are important in causing of pathologic changes with endogenous endotoxin. We concluded that in some test compounds it is inevitable to consider the influence of endogenous endotoxin for assessment and judgement of the results of toxicity study.

\section{References}

1. Takagi, H, Shimoji, N, Ogasawara, H, Noguchi, O, Fujii-Murakami, H, Murata, A, Harada, Y, and Inomata, $\mathrm{N}$ : Modification of pathological changes in toxicological studies due to endotoxin derived from intestinal flora. I. Microscopic findings in various organs and tissues from endotoxin-treated rats. J Toxicol Pathol 6: 89-104, 1993.

2. Berg, RD: Bacterial translocation from intestine. Exp Anim 34: 1-16, 1985.

3. Koyama, K, Ohuchi, K, and Okabe, K : Animal model for liver disease due to $\mathrm{D}$-galactosamine. In : Experimental Animal Model of Intractable Disease. Kyogoku, M, ed. Soft Science, Inc., Tokyo, 1984.

4. Grun, M, Liehr, H, and Rasenack, U : Significance of endotoxaemia in experimental "GalactosamineHepatitis" in the rat. Acta Hepato-Gastroenterol 23 : 64-81, 1976.

5. MacDonald, JR, Beckstead, JH, and Smuckler, EA : An ultrastructural and histochemical study of the prominent inflammatory response in $\mathrm{D}(+)$ galactosamine hepatotoxicity. Br J Exp Pathol 68 : 189-199, 1987.

6. Yoshitake, E and Hirata, K : Studies on the pathogenesis of early hepatic changes after endotoxin treatment in the rat. (1) Changes in hepatic parenchymal cells and non-parenchymal cells isolated periodically after endotoxin treatment. Sapporo Igaku Zasshi 57 : 237-248, 1988.

7. Tiegs, G, Wolter, M, and Wendel, A: Tumor necrosis factor is a terminal mediater in galactosamine/ endotoxin-induced hepatitis in mice. Biochem Pharmacol 138: 627-631, 1989.

8. Liehr, H, Englisch, G, and Rasenack, U : Lactulose- 
A drug with antiendotoxin effect. Hepato-Gastroenterol 27 : 356-360, 1980.

9. de Groot, GH, Schalm, SW, Batavier, P, Maas, HCM, and Schicht, I : Incidence of endotoxemia in pigs with ischemic hepatic necrosis treated by hemodialysis. Prevention of endotoxemia with lactulose. Hepato-gastroenterol 30: 240-242, 1983.

10. Al-Tuwaijri, A, Akdamar, K, and Di Luzio, NR: Modification of galactosamine-induced liver injury in rats by reticuloendothelial system. Stimulation or depression. Hepatology 1: 107-113, 1981.
11. Gaginella, TS, Stewart, JJ, Olsen, WA, and Bass, P : Actions of ricinoleic acid and structurally related fatty acids on the gastrointestinal tract. II. Effects on water and electrolyte absorption in vitro. J Pharmacol Exp Ther 195: 355-361, 1975.

12. Gaginella, TS, Haddad, AC, Go, VLM, and Phillips, SF : Cytotoxicity of ricinoleic acid (castor oil) and other intestinal secretagogues on isolated intestinal epithelial cells. J Pharmacol Exp Ther 201 : 259266, 1977. 